\title{
THE GLOBAL AND LOCAL ERRORS IN ENGLISH-INDONESIAN TRANSLATION
}

\author{
Ikmal Muhammad \\ English Literature Department \\ University of Khairun, Ternate, Indonesia \\ E-mail: ikmal5271@gmail.com \\ Suratman Dahlan \\ English Language Education Study Program \\ University of Khairun, Ternate, Indonesia \\ E-mail: suratmandahlan@unkhair.ac.id
}

\begin{abstract}
This research aims at revealing and analyzing errors made by the fourthsemester students of English Education Study Program, Khairun University. Dulay, Burt, and Krashen (1982) categorized errors into two types, namely global and local errors. Global errors refer to errors that affect overall sentence organization significantly hinder communication. While, errors that affect single element (constituents) in sentences do not usually hinder communication significantly are called local errors. The scholar focuses on analyzing students' errors in translating legal terms in English into Indonesian. This research is qualitative research that is analyzed the data descriptively. The research shows that there are many errors occurred in students' target-language text. The errors made by the students dominantly indicate local errors with the percentage of $81.57 \%$ as the errors which do not influence or disturb the readers' understanding. While, global errors' percentage is $18.43 \%$.
\end{abstract}

Keyword: global and local errors, translation, legal terms

\section{INTRODUCTION}

The translation is a challenging work for students since the intended meaning of the source language should be considered before translating it into a target language. Currently, many English language students tend to use google translation in doing translation tasks. They transfer the sentence pattern from English into Indonesian that consequently causes many errors that occurred in the result of their translations (Retnomurti and Imran, 2013).

Errors in translation mostly result from the non-equivalence between the source and target languages
Baker, (1992: 20-21 cited in Suksaeresup and Ackrapong, 2009). However, good translators with encyclopedic knowledge and linguistic knowledge of both the source and target languages know how to deal with them; therefore, errors can indicate the quality of a translation; moreover, they can reveal what is going on in the translator's thinking process.

In the translation field, translators' purpose is to find an accurate and equivalent in target language text. To find the equivalence, a translator should understand some requirements to avoid errors. In looking into the translator's mind, we 
may be able to give an explanatory account of the source of an error, which will throw some light on how to address problems in translation and thus improve the translation quality (Suksaeresup and Ackrapong, 2009). Generally, students get a problem in translating a specific English text, such as medical, economics, politics, and legal. It happens to the students of the English education department. Even, they have learned translation and English for Specific Purposes (ESP) subjects but in translating a text relates to legal is very difficult, because they lack of English legal terms. Many students translate a textonly focus through word for word. Therefore, they get errors in translating terms relating to ESP.

Moreover, a translation error is usually a translation problem that has not been solved or has not been appropriately solved. It outlined the research problem and its context. It also looked at the objectives of the research and various definitions of kinds of errors made by the students and, or translators. It is presented students errors' in translating legal terms in English text that caused by legal terminology. Moreover, this reserach deals with error analysis that provides information on students' errors which in turn helps the researcher to correct students' errors and also improves the effectiveness of their translation. It has been conducted to identify strategies that students use in language learning, to track the causes of the students' errors, obtain information on common difficulties in language learning or on how to prepare to get a good translation from the result of the source language to the target language.

\section{REVIEW OF RELATED LITERATURE}

In language teaching and learning process, we always find errors or mistakes that made by students. Before starting to analyze the errors, at first we are going to differenciate between error and mistake. Error and mistake are not the same, it is crucial to make distinction between error and mistake and most of people still misunderstand about the definition of them. Brown (2000: 217) defferenciates that errors and mistakes technically two very different phenomena. A mistake refers to a performance error that is either a random guess or a "slip," in that it is a failure to utilize a known system correctly.

The significance of errors in language learning was first introduced by Corder (1967). He proved that strategies of second language (L2) learners could be inferred through the analysis of their errors and that could be helpful for researchers of L2 learning process. While, Norrish (cited in Corder, 1998: 12) made a clear distinction between errors and mistakes. It is added that when a learner of English as a second or foreign language makes an error systematically, it is because he or she has not learnt the correct form. Norrish (ibid) defined mistakes as "inconsistent deviation." When a learner has been taught a certain correct form, and he uses one form sometimes and another at other 
times quite inconsistently, the inconsistent deviation is called a mistake. Systematically analysis errors made by language learners make it possible to determine areas that need reinforcement in teaching.

Error is a type of linguistic analysis that focuses on the errors students made. It consists of a comparison between the errors made in the Target Language (TL). Corder (cited in Brown, 2000) observed that Error analysis (EA) took a new turn. For learners themselves, errors are indispensable, since the making of errors can be regarded as a device the learner uses in order to learn.

Another definition of error is also given by Brown (2000). He defined error analysis as "the process to observe, analyze, and classify the deviations of the rules of the second languages and then to reveal the systems operated by learner". As stated by Samara (2003), the errors can be viewed as " a type of linguistic analysis that focuses on errors committed by learners". Corder (1967) views errors as valuable information for three beneficiaries: for teachers, it clues them on the progress of the students; for researchers, it provides evidence as to how language is acquired or learned; for learners themselves, it gives them resources in order to learn.

According to Brown (2007), there are two main sources of errors, namely, interlingual errors and intralingual errors. Interlingual (interference) Errors are those errors that are traceable to first language interference. These errors are attributable to negative interlingual transfer. According to Kim (2017), transfer of errors may occur because the learners lack the necessary information in the second language or the attentional capacity to activate the appropriate second language routine. Transfers are of two kinds: positive and negative. The transfer may prove to be justified because the structure of the two languages is similar - this case is called positive transfer or facilitation, or it may prove unjustified because the structure of the two languages are different - that case is called 'negative transfer' or 'interference'.

\section{Source or Errors}

\section{Intralingual Error}

Intralingual error is a prime factor of error, where the students produce the errors because of the wrong application of incomplete understanding. The students get misunderstanding about the rules of foreign language learning. Brown (2000) argues that as learners' progress on the second language, their previous experience and their existing subsumes begin to include structures in the target language itself. It can be said that this error reflects the students' less competence of target language rules.

\section{Interlingual Error}

Interlingual error is a significance source of error towards all learners (Brown, 2007). While, James (1987: $3)$ explained that interlingual error is different from one's mother tongue and target language as well. He suggested that a system which holds a half-way position between knowing and unknowing target language. It can be concluded that interlingual error occurs caused by the interference of mother tongue. Brown (2000) also stated 
interference is the source of error as he gives overgeneralization as a representation of interlingual transfer

\section{Types of Errors in Translation Local Error}

Local error does not prevent the message from being heard, because there is only a minor violation of one segment of a sentence, allowing the hearer, reader and or translator to make accurate guess about the intent meaning. Local error usually needs not to be corrected since the message is clear and correction might interrupt a learner in the flow of productive communication. That is why, it needs correcting. According to Brown (2007), local error is a deviation that does not interfere the fluency of communication. Although there are some types of language error, it does not cause misunderstanding. While, Kiparsky (cited in Brown 2007) stated that local errors are error that affect the overall organization of the sentence hinder successful communication, while errors that effect a single element if the sentence usually do not hinder communication. In other word, A local error is an error which is not influence or disturb the readers' understanding.

\section{Global Error}

According to Richards (1974), global error hinders communication. He defines as those that violate rules involved in the overall structure of a sentence, the relation of constituent clauses or in a sentence. Moreover, it is similar with Brown (2007), that global errors are the error hinder communication, they prevent the reader from comprehending some aspects of message. It can be concluded that global error is a kind of error which can interfere the meaning of the text so that the reader will get misunderstanding. From the explanation above, it is concluded that global error is general error that is made by speaker or translator which involve the overall structure of a sentence.

\section{Translation}

Translation is a process of finding equivalent in TL text. According to Nida and Taber (1975), translation consists of reproducing in the receptor language the closest natural equivalent of the sourse language message, first in term of meaning and second in terms of style. The information provided by the commissioner allows the translator to rank issues of concern in order before deciding on inclusions, omissions, elaborations, and whether the translation should have source of translation and theory for translation priority. According to Catford (1974), translation may be defined as the replacement of textual material in one language by equivalent textual material in another language.

\section{METHOD}

This reserach deals with qualitative research which analysed the data descriptively (Gass \& Selinker (2008). The data of this research was collected by taking students' worksheet of translation subject. This research gained the data from 15 students to be analyzed qualitatively. The data was a translated text by the fourth semester 
students of English Education Study Program, Khairun University.

\section{Procedure of Collecting Data}

The procedure of the research involves the following steps:

1. Before giving the text to be translated, the students were asked to deliver problem that they face in translation field, especially translating a specific text. It is intended to know the prior knowledge of the students' translation competence, then giving students a text in English to translate into Indonesian.

2. After giving the text, the students were given 90 minutes to translate the text. The aim of the test is to know the students' errors in translating a specific text retaled to legal context.

3. After translating the text, the researcher collected the data to be analysed. Moreover, students' translation errors analysed were calculated into percentage by applying the following formula and tabulated (Krisetyawati, 2010):

$$
\begin{aligned}
\mathrm{P}(\%)=\frac{p}{i} \times 100 \% \\
\mathrm{E}=\text { error percentage } \\
p=\text { the number of errors } \\
i=\text { the total number of errors }
\end{aligned}
$$

\section{FINDINGS AND DISCUSSION}

The most important aspects of translating is that it always occurs within a context of texts to be translated into target language. When translators translate a text means that the translators are using both language to carry out various social functions and choosing forms of language which relate in an equivalent of specific terms. The

\begin{tabular}{|c|c|c|c|}
\hline Source language & $\begin{array}{l}\text { Students' } \\
\text { Target }\end{array}$ & $\begin{array}{l}\text { Correct Form in } \\
\text { Target Language }\end{array}$ & $\begin{array}{l}\text { Kinds of } \\
\text { Error }\end{array}$ \\
\hline $\begin{array}{l}\ldots \text { pressured the } \\
\text { government to drop its } \\
\text { manpower bill. }\end{array}$ & $\begin{array}{l}\quad \text { Language } \\
\text {... memaksa } \\
\text { pemerintah } \\
\text { untuk merevisi }\end{array}$ & $\begin{array}{l}\text {...memaksa } \\
\text { pemerintah untuk } \\
\text { membatalkan }\end{array}$ & Local Error \\
\hline & $\begin{array}{l}\text { rancangan } \\
\text { tenaga kerja } \\
\text { baru (no. } 1 \\
\text { subject 6). }\end{array}$ & $\begin{array}{l}\text { rancangan undang- } \\
\text { undang (RUU) } \\
\text { tenaga kerja (no. 1). }\end{array}$ & \\
\hline ... a non government & ... yang bukan & ... lembaga swadaya & \\
\hline & $\begin{array}{l}\text { dari } \\
\text { pemerintah } \\
\text { dipangil (no. } 3 \\
\text { subject 6). }\end{array}$ & $\begin{array}{l}\text { masyarakat yang } \\
\text { menyebut (no. 3). }\end{array}$ & Local Error \\
\hline
\end{tabular}
errors can seen in the following table.

Table 1. Classification of Students' Errors 


\author{
...gathered at the \\ house and waved \\ placards denouncing \\ the bill.
}

... if passed, would fail to protect Indonesian women working abroad...

the police to discover what caused Neneng to die, ...

.. the workers were originally scheduled to meet with the legislators today.
.... some house members had agreed to meet this morning with...

...berkumpul di
gedung dan
memasang
poster di papan
iklan (no. 4
subject 6).

...jika melewati akan gagal untuk memprotes pekerja wanita Indonesia di luar negeri... (no. 5 subject

6).

$$
\text { ...asuransi }
$$
pembayaran dari anak-anak saya, Neneng, yang sudah meniggal (no. 9 subject 6). ...mengatakan pekerja mula mula membuat jadwal untuk bertemu dengan pembuat UndangUndang hari ini (no. 10 subject 6)

...beberapa
rumah anggota
sudah
menyetujui
pagi ini ...
(no. 12 subjcet
6 ).
...menuduh
pemerintah
untuk menarik

...gedung DPR dan

melambai-

lambaikan plakat

yang mencelah

rancangan undang-

undang tersebut (no.

4).

...jika disahkan tidak dapat melindungi TKW

Indonesia di luar negeri...(no. 5).

Global

Error

Local Error

..polisi menemukan apa penyebab

Global

Neneng sampai

Error

meninggal (no. 9).

..mengatakan

bahwa para pekerja

sebenarnya

dijadwalkan

menemui para

dewan sekarang.

(no.10)

Local Error

.. beberapa anggota dewan telah setujuh Global

bertemu pagi ini Error

bersama- sama dengan....(no. 12).

...menyalahkan

pemerintah atas

penyusunan UU

Local Error 
Jurnal Penelitian Humano, Vol. 10 No. 1 Edisi Juni 2019

$\begin{array}{lll}\text { manpower bill. } & \text { kembali } & \text { tenaga kerja tersebut. } \\ \text { rancangan } & \text { (no. 14) } \\ & \text { Undang } \\ & \text { Undang (no. } \\ & 14 \text { subjcet 6). }\end{array}$

Based on the table 1, there are some errors that made by students in translating legal terms. For example:

..."scheduled to meet with the legislators today". The subject translated the term legislators: pembuat UU. The term legislators should be translated "para dewan, the sentence will be (...dijadwalkan menemui para dewan sekarang). Moreover, terms: some house members translated as anggota legislator in Indonesian. The term house members: should be; anggota dewan. Therefore, the sentence will be (....beberapa anggota dewan telah setujuh bertemu pagi ini bersama- sama dengan para pengunjuk rasa). Those errors are categorized as local error because the message can be understood by readers. Furthemore, global errors are the error hinder communication,

the translation result prevents the readers of comprehending some aspects of message.

For example:

....of Karawang pressured the government to drop its manpower bill. The student translated the term pressured: menekan, to drop: menjatuhkan, and manpower bill: tagihan kerjanya. The equivalent terms in Indinesian actually should be pressured: memaksa, to drop: membatalkan, manpower bill: Rancangan Undang-undang tenaga kerja. Therefore, the sentence will be (...memaksa pemerintah untuk membatalkan rancangan undangundang tenaga kerja). The errors are categorized as global error because the reader will not be able to understand the message of the translation result in target language text.

Table 2. Percentage of Errors

$\begin{array}{cccc}\text { Number } & \text { Types of Error } & \text { Frequencies of } & \text { Percentage of } \\ 1 & \text { Local Errors } & \text { Errors } & \text { Errors } \\ & & 31 & 81.57\end{array}$

2 Global Errors

Based on finding of local and calculated the average of students' error at local is 81.57 , while global global errors, the researcher showed the percentage in 18.43 . The 
following are discussed about the results of the students' data in translating legal terms in English text. It was obtained by using a text to be given for the students to produce the legal terms in target language text of Indonesian. It is relating to the errors in translation, which is classified into two kinds of errors viewed from the effect of communication, such as global and local error. The data showed that many students produced the local errors in target target language. Global errors caused readers get difficulty to understand what exactly the point of the text which the students want to translate. It is supported by the statement of Brown (2007) that global errors are the error hinder communication, they prevent the reader from comprehending some aspects of message.

Moreover, some students made errors which classified to local error as their errors which do not interfere the meaning of the text. As stated by Ellis (1997 cited in Utami, 2017), that local errors refer to errors that affect only a single constituent in the sentence and are less likely to create any processing problem. That means that although the errors are existed in target language translation, but the readers still understand the message of the text itself. Some of them produced their target language terms from English as source language into Indonesian as target language directly without giving attention to the rule of translation and the term's meaning. The less understanding or wrong application in translating then categorized as intralingual errors. The data shows that there are few participants made intralingual error. Some participants made an interlingual error caused by overgeneralization or interfered by their habit in Indonesian language. Brown (2000) stated that interference is the source of error as gives overgeneralization as a representation of interlingual transfer.

\section{Diagram of Errors Percentage}

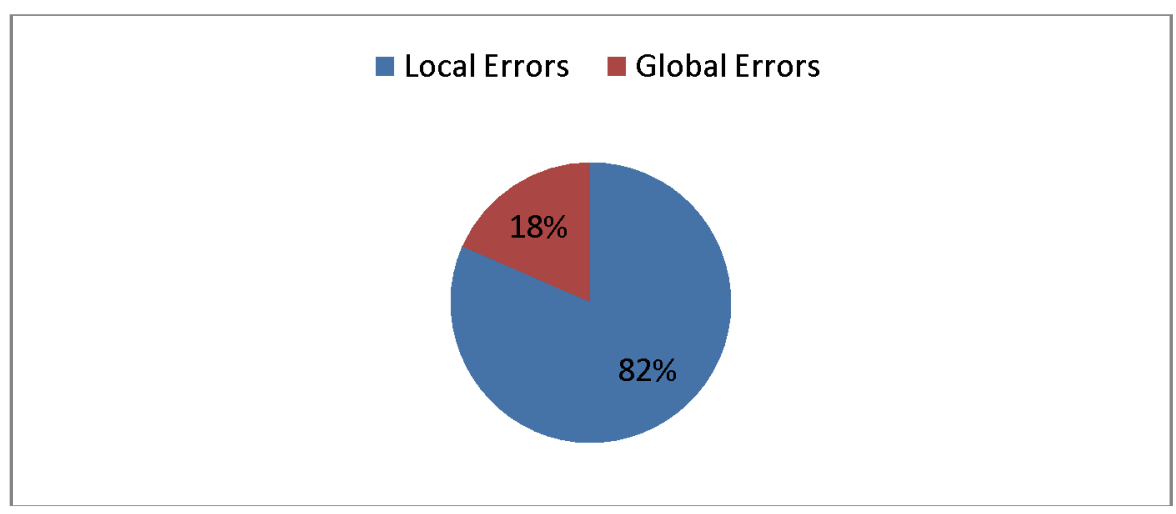


The diagram shows that the errors made by students dominantly indicate local errors. Besides that, related to the source of errors, it is dominantly classified as interlingual.

\section{CONCLUSION}

Based on the discussion, it can be concluded that the students' errors viewed from the effect of communication as local and global error and also the source of error which classified to interlingual and intralingual errors. Mostly, the students made a local errors and interlingual error related to their errors in translating legal terms in English text. Local errors mean that the errors that produced by the translator which not influence the meaning target language text. This is different with global error as the errors which can influence the meaning of the text, therefore readers can get misunderstanding. Interlingual errors are the source of errors caused by the interference in Indonesia. The intralingual errors are caused by incomplete understanding of English rule and the wrong application of English as source text.

\section{REFERENCES}

Baker, Mona. 1992. In Other Words: A Course Book on Translation. London: Ruotledge.

Brown, H. 2007. Principles of Language Learning and Teaching. New Jersey: Prentice-Hall Inc.

Brown, H. Douglas. 2000. Principles of Language Learning and
Teaching Fourth Edition: Addition Wesley Longman.

Brown, H. Douglas. 1994. Principle of Language Teaching, Camridge: University Press.

Corder, S.P. 1998. Error Analysis, Interlanguage and Second Language Acquisition, Language Teaching and Linguistics: Abstracts, 8, 201218.

Corder, S. P. 1967. Error Analysis: Perspectives on Second Language Acquisition. London: Longman.

Catford, J.C. 1974. A Linguistic Theory of Translation. Oxford: Oxford University Press.

Catford, J.C. 1965. A Linguistic Theory of Translation: An Essay in Applied Linguistics, Oxford University Press, London, New York, and Toronto.

Dulay, H., Burt, M. and Krashen, S. 1982. Language Two. New York: Oxford University Press.

Gass, S., \& Selinker L. (2008). Second language acquisition: An introductory course (2nd ed.). New York, Routledge.

Krisetyawati, B. F. 2010. An Error Analysis of the Translation of Noun Phrase into Indonesia, English Department of Teacher Training and Education Faculty. Sebelas Maret University. Surakatra.

Larson, M. 1992. Meaning-Based Translation. USA: University Press of America, Inc.

Nida, E.A. \& Taber. 1975. The Theory and Practice of Translation. Leiden: E.J. Brill. 